\title{
Large-scale mining and ecological imperialism in Africa: the politics of mining and conservation of the ecology in Ghana
}

\author{
Jasper Abembia Ayelazuno ${ }^{1}$ \\ Lord Mawuko-Yevugah \\ University for Development Studies, Ghana \\ Ghana Institute of Management and Public Administration, Ghana
}

\begin{abstract}
The article draws on the insights of political ecology to illuminate the politics shaping the enforcement of environmental regulation in the mining sector of Ghana. We argue that the Ghanaian state uses strong-arm measures against artisanal and small-scale mining (ASM) operators, particularly, the subaltern classes engaged in the industry for survival. Periodically, the state deploys the military and the police to clamp down on ASM for destroying the environment, but treats with kid gloves foreign companies engaged in large-scale mining (LSM), wreaking similar disastrous ecological effects on mining communities. The state believes that LSM by foreign companies is a source of foreign direct investment (FDI) and foreign mining companies should be incentivized to come and stay in the country. Presented in broad-brush strokes as illegal (galamsey), the Ghanaian state sees ASM as an environmental menace to be fought with all the coercive apparatuses that it can command. Disputing this claim, the article argues that mining-FDI is essentially ecological imperialism, wreaking havoc on the ecosystem of mining communities whose livelihood strategies are in conflict with the accumulation and political interests of foreign mining companies and the Ghanaian political class respectively. The article demonstrates that concerns over the harmful impacts of mining on the ecology of Ghana are neither class-neutral nor free of politics. They are rather highly imbricated in power structures and relations, in which the interest of the ruling class is supreme in the enforcement of environmental regulations in Ghana. The paradox of the biases of the Ghanaian state against ASM, particularly ASM operated by its own citizens for survival, and in favor of foreign mining companies engaged in LSM for profits, is explained with the insights of ecological imperialism.
\end{abstract}

Keywords: Large-scale mining, artisanal and small-scale mining, Operation Vanguard, Ghanaian state biases, ecological imperialism

\section{Résumé}

L'article s'appuie sur les connaissances de l'écologie politique pour éclairer les politiques qui déterminent l'application de la réglementation environnementale dans le secteur minier du Ghana. Il fait valoir que l'État ghanéen a recours à des mesures énergiques à l'encontre des exploitants de petites exploitations minières artisanales et minières, en particulier des classes subalternes engagées dans l'industrie pour leur survie. Périodiquement, l'État déploie des forces militaires et la police pour réprimer l'ASM pour la destruction de l'environnement, mais traite de manière moins clémente les sociétés étrangères impliquées dans l'exploitation minière à grande échelle (LSM), bien qu'elles aient des effets écologiques désastreux sur les communautés minières. L'État estime que le LSM par des sociétés étrangères est une source d'investissement direct étranger (IDE) et que les sociétés minières étrangères devraient être incitées à venir et à rester dans le pays. l'État ghanéen considère l'ASM comme une menace environnementale à combattre avec tous les appareils coercitifs

1 Dr. Jasper Abembia Ayelazuno, University for Development Studies (UDS), Tamale, Ghana. Email: abembia@yahoo.com. Dr. Lord Mawuko-Yevugah, Ghana Institute of Management and Public Administration (GIMPA), Ghana. Email: lmawuko@gimpa.edu.gh. This article is based on a research project sponsored by the Volkswagen Foundation Postdoctoral Fellowship in the Social Sciences in Sub-Saharan and North Africa. The authors are very grateful to the Volkswagen Foundation for sponsoring this research, and to the journal reviewers/editors for their helpful comments. 
qu'il peut commander et le présente comme illégal (galamsey). Remettant en cause cette affirmation, l'article affirme que l'IED minier est essentiellement un impérialisme écologique, ravageant l'écosystème des communautés minières dont les stratégies de subsistance sont en conflit avec l'accumulation et les intérêts politiques des sociétés minières étrangères et de la classe politique ghanéenne. L'article démontre que les préoccupations concernant les impacts néfastes de l'exploitation minière sur l'écologie du Ghana ne sont ni neutres en termes de classe, ni exemptes de toute politique. Ils sont plutôt fortement imbriqués dans les structures de pouvoir et les relations, dans lesquelles l'intérêt de la classe dirigeante est suprême dans l'application des réglementations environnementales au Ghana. L'État ghanéen est contre l'ASM, en particulier l'ASM gérée par ses propres citoyens pour sa survie. Pourtant, il soutient les sociétés minières étrangères engagées dans le LSM à but lucratif. Ce paradoxe s'explique par les idées de l'impérialisme écologique.

Mots-clés: Exploitation minière à grande échelle, exploitation artisanale et à petite échelle, Opération Vanguard, biais de l'État ghanéen, impérialisme écologique

\section{Resumen}

Este artículo se basa en las ideas de la ecología política para iluminar el aspecto político que estructura la aplicación de las regulaciones ambientales en el sector minero de Ghana. El texto discute que el estado ghanés utiliza medidas represivas en contra de operadores, particularmente de las clases subalternas involucradas en la minería artesanal y a pequeña escala (ASM) como modo de supervivencia. Periódicamente, para reprimir la ASM por destrucción del ambiente, el estado despliega policía y milicia. Sin embargo, las compañías extranjeras dedicadas a la minería de gran escala (LSM) y que causan igualmente efectos ecológicos desastrosos en comunidades mineras, son tratadas con "guantes de seda". El estado considera que la LSM por parte de empresas foráneas, es una fuente de inversión extranjera directa (FDI) y que dichas compañías deben ser incentivadas para llegar y establecerse en el país. Presentada a grandes rasgos como ilegal (galamsey), el estado ghanés ve la ASM como una amenaza ambiental que debe ser combatida con todo el aparato coercitivo que se pueda dirigir. Para discutir esta afirmación, el artículo argumenta que la minería FDI es, en esencia, imperialismo ecológico causando estragos en los ecosistemas de comunidades mineras, cuyas estrategias de subsistencia están en conflicto con la acumulación y los intereses políticos tanto de compañías mineras extranjeras y la clase política ghanesa. El artículo demuestra que las preocupaciones por los impactos nocivos en la ecología de Ghana por parte de la minería, no son ni neutrales en cuanto a clase, ni ajenos a la política. Por el contrario, están severamente integradas en las estructuras y relaciones de poder, donde los intereses de la clase dominante ghanesa son fundamentales en la aplicación de las regulaciones ambientales. La paradoja de los sesgos que tiene el estado ghanés contra la ASM, particularmente la que es operada por sus propios ciudadanos que con ella buscan la supervivencia, y que además tiene en favor de las compañías mineras extranjeras dedicadas a la LSM para obtener ganancias, se explican con las ideas del imperialismo ecológico.

Palabras clave: minería a gran escala, minería artesanal y a pequeña escala, Operación Vanguardia, sesgos del estado ghanés, imperialismo ecológico

\section{Introduction}

A large oeuvre of literature, scholarly and grey, documents and severely criticizes the Ghanaian state and foreign mining companies for the violence they wreak on inhabitants of mining communities. The Ghanaian state is also criticized for its biases in policy, actions, and inactions in favor of large-scale mining (LSM) and against artisanal and small-scale-mining (ASM). This violence and these biases have been documented empirically, as have the inherent enclave economic tendencies and characteristics of mining and other extractive industries under the neoliberal world order (Ferguson 2005). How policies and actions engender not development, but new imperialist/neocolonialist exploitation and 'accumulation by dispossession' in Ghana has also been addressed (Andrews 2018; Ayelazuno 2011). We seek to contribute to this body of literature by drawing on the insights of political ecology; in particular, the competition for and conflicts over the appropriation of natural resources by powerful and powerless classes, vis-à-vis the unequal distribution of the negative environmental effects of this appropriation between different classes of people and regions of the world. So often, the biases of the government of Ghana in favor of LSM and against ASM are illustrated by the generous investment incentives it gives to corporations (see Ayelazuno 2011; Hilson and Hilson 2017; Hilson 2017). We seek to amplify and explain an additional, albeit marginalized, dimension of these biases: 
ecological biases. Similarly, the discourses on the new imperialism and neocolonialism of mining are often focused on analyzing the economic and political dynamics of exploitation of minerals and other non-renewable natural resources by global extractive capital. We try to push the discourses and analysis of imperialism in Africa beyond the economic/political to the ecological. We will argue that mining-related foreign direct investment (FDI), far from being a force of development, is essentially the manifestation of 'ecological imperialism' in Ghana (Clark and Foster 2009).

In the pages that follow, we flesh out our arguments: in the next section we address the charge of ecological biases we make against the Ghanaian state by discussing the strong-arm measures it uses against ASM operators for destroying the ecology on one hand, and on the other, its inaction against LSM by foreign mining companies whose mining activities wreak disastrous environmental effects on mining communities. In the third section, we unpack 'ecological imperialism', pinning down its core dynamics and characteristics to provide the theoretical framework for discussing the empirical material in the penultimate section. In the empirical core of the article we present and discuss evidence of ecological imperialism; namely, the destruction of the ecosystem by foreign mining companies engaged in LSM in Ghana. The conclusion also comments on the theoretical contribution to the mining literature on Ghana.

\section{Ecological biases of the Ghanaian state: military operations against ASM, nothing against LSM}

Mining of all shades and forms is inherently a polluting and environmentally damaging industry. Whether undertaken on a small-scale with rudimentary equipment or on large-scale with sophisticated equipment, the processes of mining, mineral processing, and beneficiation are pregnant with dangerous chemicals which are discharged into the ecosystem; into the air, land, water, and human beings and other animals (Bell and Donnelly 2006). Yet - and as we illustrate below - some of the harshest strong-arm tactics of the government of Ghana to control mining-induced environmental destruction have been biased against artisanal and small-scale mining (ASM) engaged in by the subaltern classes; namely, poor Ghanaians 'digging for survival' (Andrews 2015). Paradoxically, large-scale mining (LSM) engaged by multinational and foreign mining companies to accumulate more and more money is treated with kid gloves. The Ghanaian state is certainly aware of the environmental degradation that LSM causes, especially in its current surface-mining form. It skirts the responsibility to act with similar force and violence in accordance with the principles of natural justice because it views LSM by foreign mining companies as a 'growth pole' (Hilson 2017); and as a sector of the economy that attracts foreign direct investment (FDI) with many positive multiplier effects on various sectors of the Ghanaian economy. The biases in favor of LSM are not just a Ghanaian problem, but exist across continental Sub-Saharan Africa. A recent study, a tour de force of the review of the state-of-theart literature on environmental policies on mining in the continent, found out that "most mining policies in Africa favor large-scale industrial gold mining while their counterparts in the ASM sector are neglected and demonized" (Tuokuu 2019: 38).

Perhaps, the biases of the Ghanaian state are nowhere better demonstrated than by its periodic, albeit politically opportunistic, violent crackdowns on ASM. These involve the deployment of the military and police to arrest, detain, destroy mining tools, and assault and harm subaltern groups engaged in the industry for survival. The result is egregious human rights abuses in mining communities (Commission on Human Rights and Administrative Justice [CHRAJ] 2008). Far from taking similar harsh measures against LSM, the state has stationed soldiers at the security posts of LSM companies to provide 24-hour security for their operations. These soldiers are accused by members of mining communities of engaging in acts of violence against them (CHRAJ 2008). The excuse for these biases is that ASM operate illegally while LSM operate legally, including the possession of valid environmental permits issued by The Environmental Protection Agency of Ghana (EPAG) in accordance with the Ghana Environmental Assessment Regulations 1999, LI 1652 and the Minerals and Mining Policy of Ghana 2014.

It is not within the scope of this article to discuss the legality and illegality of LSM and ASM respectively, and why the latter has been labelled galamsey, a shorthand for its inherently illegal and environmentally disastrous character; and thus, is vilified as a monster while LSM is glorified as a source of 
FDI. It will suffice just to say that even though ASM is predominantly an informal economic activity, mostly unlicensed - particularly the gold mining engaged by the subaltern classes - the issue is far more complex than the caricature of galamsey or illegal mining often seen in the mainstream Ghanaian media and in political discourses. The illegality and informality of ASM is caused by the state itself in large measure, but worse, the decision to act to stop it is so often politicized. It has varied from tacit complicity and inaction by the political class to violent military crackdowns like Operation Vanguard, when it is politically opportune (see Crawford et al. 2015; Crawford and Botchwey 2018; Hilson 2017). Similarly, the possession by LSM companies of valid environmental permits issued by the Environmental Protection Agency of Ghana (EPAG) should not be equated with compliance with environmental, health, and safety rules in their mining operations. As documented in the penultimate section, there are numerous cases of environmental pollution and tragic mining accidents in LSM. The regulatory agencies responsible for enforcing and monitoring the compliance of environmental and health and safety rules lack capacity to do so (Domfeh 2003; Hira and Busumtwi-Sam 2018; UNDP 2015). The outcome is that the LSM sector has equally damaging effects on the ecology as does ASM.

As mentioned, military clampdowns on ASM are illustrative of the biases of the Ghanaian state against and in favor of ASM and LSM respectively in its so-called determination to protect the environment. It seems these biases cut across all Ghanaian governments and leaders of the last 30 years, spanning the regimes of Presidents Jerry John Rawlings, John Kufuor, John Atta Mills, John Mahama, and Nana Akufo-Addo. As one authoritative research report notes:

Since 1989 governments have engaged periodically in exercises involving the police and/or army to weed-out and close illegal ASM operations. For example, in 2006, the national government carried out operation "Fight against Illegal Mining", financed by large mining companies under the auspices of the Ghana Chamber of Mines. The National Security Council organized the operation, using the army to sweep unlicensed miners, destroying equipment and arresting ASM operators. (Hira and Busumtwi-Sam 2018: 40)

Operation Fight against Illegal Mining used a trinity of powerful players to bring their might and money against weaker ones in the mining industry. It was financed by the Ghana Chamber of Mines - an association that advocates and protects the class interests of capitalist mining and large-scale mining companies. Illegal mining here is more than a legal definition; it also means that in the struggle for natural resources, those who have power and money can use them to effectively wipe out their weaker competitors, the subaltern classes digging for survival (Andrews 2015).

In 2013, another police-cum-military operation, Operation Flushing Out was mounted against ASM. Following reports of Chinese involvement in galamsey, the National Democratic Congress (NDC) government, led by Mr John Mahama, formed a high-level Inter-Ministerial Task Force in May to combat illegal smallscale mining. The taskforce was charged with the responsibility "...to flush out Ghanaians and foreigners engaged in illegal mining in the country" and was asked to "work in a coordinated manner with the military and the police to arrest and prosecute Ghanaians and foreigners engaged in illegal mining" (Daily Graphic, cited in Asamoah and Osei-Kojo 2016: 6). Operation Flushing Out led to the arrest of 1,568 foreigners and 51 Ghanaians, the deportation of 3,877 foreigners, the seizure of forty vehicles, 85 excavators and 49 weapons (Crawford et al. 2015: 32).

Most recently, in 2017, the Akufo-Addo-led New Patriotic Party (NPP) government again mounted a similar operation - Operation Vanguard - against ASM because of the same environmental concerns as those driving the 2006 and 2013 operations (see Crawford et al. 2015; Hilson 2017). It also placed a blanket ban on the operations of ASM, including licensed ASM operators; thus, abusing the rights of the latter to operate a legitimate and licensed business. Preceding Operation Vanguard and the ban were sustained media campaigns and political rhetoric demonizing ASM as the cause of a looming environmental disaster in Ghana. Citi FM, an Accra-based radio station, took to Twitter to mobilize public opinion against galamsey and to pressurize the Ghanaian government to act quickly to stop this 'menace.' With the Twitter handle \#StopGalamsey, the campaign quickly got the "support of other local media outlets and produced a lengthy petition that included 
signatures from key ministerial figures - past and present - which Citi FM personnel presented to Parliament on 7 April 2017" (Hilson 2017: 110). Illustrative of the media using its power against ASM generally, and in particular, the mining undertaken by the poorest of the poor for survival, the signatories of Citi FM's petition included powerful media organizations such as high-ranking officials at the Graphic Communication Group Limited, the Ghana Independent Broadcasters Association (GIBA), the Ghanaian Times, the Ghana Journalists Association, the Ghana Broadcasting Corporation and the Christian Council (Hilson 2017: 110). The Ghanaian president, Mr. Nana Akufo-Addo lent the media campaign political support. He vowed to put his Presidency on the line to fight the galamsey menace. He also upped the ante in the war against environmental degradation by illegal mining. He continuously referred to galamsey as a 'menace', and in his public speeches, he often talks about the 'fight against illegal mining', the 'war against galamsey' and 'the fight against galamsey' (Hilson 2017: 111).

The incumbent government, led by President Akufo-Addo, took a number of drastic actions aimed at stopping the so-called menace. As mentioned above, on the 1st of April 2017, it placed a blanket ban on artisanal and small-scale mining operations for a period of six months; it suspended the issuance of new licenses for small-scale mining for a year; established an inter-Ministerial Committee on Illegal Mining (IMCIM) in April 2017, charged with the responsibility to address illegal mining; and on 31 July 2017, launched Operation Vanguard made up of four hundred men drawn from the military and police service, deployed to mining areas mainly in the Eastern, Central, Ashanti and Western Regions to enforce the ban. Operation Vanguard is credited with some successes. As of February 2018, it had made 1,031 arrests in Ashanti, Eastern and Western regions. In addition to the arrests are the confiscation of mining equipment and arms and ammunitions, 173 excavators, 60 vehicles, 274 water pumps, 87 assorted arms, and 1,382 pieces of ammunition (Graphic Online/Yeboah, 21 February 2018). Ninety-five of those arrested have been successfully prosecuted and convicted, but most of them are on bail, pending trials which have been adjourned many times (Citifmonine.com, 31 January 2018). There have been reports of human rights abuses by Operation Vanguard. They include:

....army officials setting 10 excavators ablaze, unlawfully, because they were 'taunted'; the destruction of over 2,000 Chinese-fabricated 'Chang Fa' machines in Atwima Mponua, Amansie West, Amansie East, Konongo and other districts in the Ashanti Region; the alleged shooting and killing of a galamsey operator in Wawasi, also in the Ashanti Region; and hundreds of arrests. (Hilson 2017: 111)

The activities of the taskforce are still ongoing. For example, on May 15, 2019, the Daily Graphic reported that 50 suspected illegal miners - 34 Ghanaians, 10 Chinese and six Nigerians, were rounded up from various illegal gold mining sites by the joint security taskforce, Operation Vanguard (Graphic online, 2019b).

Yet Operation Vanguard - just like the other operations before it - is burdened with the dishonest and dirty politics and elite class interests that have spawned galamsey in the first place, and then the unsuccessful fight against it for decades. Space constraints rule out a detailed discussion of this issue, but leading figures of the campaign against galamsey are voicing their disappointment with Operation Vanguard and the incumbent government because of revelations that powerful politicians and other elites are protecting segments of ASM operators or circumventing criminal proceedings against them. The Convener of the Media Coalition against Galamsey, Kenneth Ashigbey, was compelled to admit that foreigners, mostly Chinese, who are the "conveyor belts of galamsey" are "still trooping into the country to engage in the activity" (Ghanaweb.com 2018). The Managing Editor of the New Crusading Guide newspaper, Kweku Baako Jnr. - who supports the war against galamsey and is one of the stalwart defenders of the incumbent NPP government for various highly rated media programmes - said that despite some successes, Operation Vanguard has some negatives, which, "if not checked can collapse the entire campaign. The potential for the spectacular failure is there; the seeds are there" (Ghanaweb.com 2019b). A clear signal was the Ghanaian state's decision to discontinue the prosecution of a Chinese woman, Aisha Huang, also known as the 'galamsey queen.' The Senior Minister of President AkufoAddo's government, Mr Yaw Osafo-Maafo, illustrating the power dynamics and politics surrounding the enforcement of environmental protection laws in mining, justified the discontinuation of the case against Aisha 
Huang. In simple terms, she is Chinese, and China gives a lot of development aid to Ghana. Prosecuting her will be bad, diplomatically, for Ghana (Ghanaweb.com 2019a).

Aisha Huang is not only notorious for her illegal mining activities in Ghana, but also for her alleged tricks in gaining huge clout over powerful Ghanaian elites, including top officials of government, and using them to protect her illegal mining activities (Ghanaweb 2017). Kweku Baako Jnr, renowned for his investigative journalism - able to get access to sensitive and highly-guarded information about the political elites of Ghana - lends credence to this assertion. Contributing to a discussion on the fight against galamsey on Newfile, one of the highly rated weekend political talk shows in Ghana, he stated that Aisha Huang and her partners are very powerful Chinese women, well-connected politically to powerful people in both NDC- and NPP-led governments in Ghana. He suggests they offer favors to these powerful politicians in exchange for protection of their illegal mining activities from the law enforcement agencies (Myjoyonline TV n.d).

Also illustrative of the politics of discriminatory enforcement of mining environmental laws is the puzzling inaction of the Ghanaian state when LSM companies degrade the natural environment in mining communities. To the best of our knowledge, there are no strong-arm actions against large-scale mining (LSM); as if to suggest that LSM is environmentally friendly. As the penultimate section illustrates, this is not the case. Foreign mining companies engaged in LSM are spared the militarized and often violent enforcement of mining laws. Seeing LSM by foreign mining companies as the source of FDI, the Ghanaian state is more concerned to give them incentives rather than punishing them severely when they commit infractions. The state gives them a slap on the wrist when they violate environmental regulations; for example, they are asked to pay fines, as Newmont Ghana Ltd. was asked to do when it spilled cyanide into the Subri River in 2009 (see Andrews 2019: 51-52). EPAG has even resorted to using environmental disclosure and ratings methods, with AKOBEN being the latest (Sekyi 2011). Using the colors gold, green, blue, orange, and red, representing a spectrum of performance indicators from excellent to poor, EPAG rates mining companies and discloses their performance to the media and public. The trick is to discipline their environmental behavior, considering that poor performance may hurt the image of the company in the community it operates, among financial institutions, and even internationally (Armah et al. 2011: 195-196; Bawua and Owusu 2018: 12; Hira and Busumtwi-Sam 2018: 15; Sekyi 2011; Tuokuu 2019: 37). If this isn't a slap on the wrist, we don't know how else to label it.

Worse, this preferential treatment may actually be given to companies operating illegally in Ghana. In violation of article 268 of the 1992 Constitution, that stipulates that the leases of mining companies must be ratified by Parliament before they can start mining, some LSM companies - including majors like AngloGold Ashanti Ghana Limited and Newmont Gold Ghana Limited - are alleged to be operating without the ratification of their leases by Parliament. The state has done nothing about this allegation. It took two Members of Parliament (MPs), Alhassan Sayibu Suhuyini and Ernest Henry Norgbey, to act: they filed a suit at the Supreme Court against 35 mining companies, the Attorney-General and the Minerals Commission for violating the highest law of the land, the 1992 Ghana Constitution (Graphic Online 2019a). Even though the Supreme Court has not yet given its judgement, the former Chief Executive of the Ghana Minerals Commission, Dr Toni Aubynn, has affirmed this illegality, based on his knowledge of the issue as a former leader of one of the leading state regulatory bodies of mining. While the confirmation of an authoritative source such as Dr Aubynn doesn't make the companies guilty, it is more than speculation that some foreign mining companies are also operating illegally, just as some ASM operators do. The difference is the inaction of the Ghanaian state in the case of the former, and the forceful action it has taken against the latter.

\section{Ecological imperialism}

In this section, we unpack ecological imperialism, distilling its core dynamics and characteristics, to provide the theoretical framework for the kernel of our argument: mining FDI is not a force for development but rather the manifestation of ecological imperialism in Africa generally, and Ghana in particular (see Clark and Foster 2009). Ecological imperialism sheds light on the disastrous ecological implications of the exploitation of Ghana by global mining capital; an aspect of imperialism so often eclipsed by the materialist thrust of mainstream discourses of imperialism, new imperialism, and neocolonialism, espoused at various times by the likes of Vladimir Lenin, Kwame Nkrumah, Samir Amin, David Harvey, and Patrick Bond. Usually 
emphasized in the classical imperialism literature are economic exploitation and the inherently unfair terms of trade in the way that Africa is integrated into the capitalist global economy. To be added to these, however, are the commodification and pillage of the ecosystems of countries and communities endowed with high-value and much-sought-after natural resources such as gold, diamonds, bauxite, and cobalt. The extraction of these resources makes mining capital one of the ferocious ecological imperialist forces in Africa.

Ecological imperialism is driven, shaped, and characterized by a number of interrelated, underlying dynamics. First, there is a single, expanding capitalist world/global economy that accumulates across the world and individual nation-states' boundaries. This economy is characterized by the international division of labor between the core, mainly consisting of advanced and industrialised economies producing and trading manufactured goods, and the periphery, with developing or less-developed, or relatively unindustrialised economies producing and trading in raw materials. 'The industrial economy', Martinez-Alier et al. (2016: 468) argue, "has a voracious appetite for fresh supplies; it goes to the commodity extraction frontiers to get new resources, in greater and greater quantities. And it deposits the waste anywhere it can (the atmosphere, the oceans, the rivers and soils...)" (See also Moore 2015: 158-160). The periphery is the "commodity extraction frontiers" (emphasis original). The core and periphery division may coincide with some geographical divisions, such as continents; but they do not necessarily equate to them, nor is the core/periphery division static and unchanging. Over time, this international division of labor has changed, with countries such as China, hitherto in the periphery, now in the core; producing and exporting manufactured goods to both the core and periphery. Analytically and ontologically, the core and periphery are better viewed as complementary parts of the world economy (see Hopkins and Wallerstein 1972; see also Biel 2012). Despite changes in the international division of labor, driven partly by neoliberal globalization, the core/periphery division is key to the conceptualization of ecological imperialism; especially with respect to Africa where the new international division of labor still leaves most of it in the periphery, consigned to the role of a quarry for drawing raw material to the core, with all the deleterious ecological effects.

Second, and closely linked to the first, we live in a single world ecology in which we are part and parcel of, yet humans also make and remake the ecology through the processes and means by which we produce and reproduce ourselves materially and socially (Moore 2015). Karl Marx in his usual eruditeness and eloquence described the organic relationship between the re(production) of human beings and nature;

Labor is, first of all, a process between man and nature, a process by which man, through his own actions, mediates, regulates and controls the metabolism between himself and nature. He confronts the materials of nature as a force of nature. He sets in motion the natural forces which belong to his own body, his arms, legs, head and hands, in order to appropriate the materials of nature in a form adapted to his own needs. Through this movement he acts upon external nature and changes it, and in this way, he simultaneously changes his own nature (Marx 1976: 283).

Human beings across the world, as the work of human and anthropological ecologists illustrates (see Richardson et al. 1996; Johnson and Earle 2000), have throughout the millennia of their existence on earth appropriated the environment to produce and reproduce themselves. From simple foraging/hunting and gathering societies to more complex industrial societies, human beings have exploited the resources of the nonhuman environment in which they live for their survival. Ecological imperialism, as discussed below, is spawned by a specific mode of appropriating the ecology, not for survival, but for money.

Third, the sustainability of the world ecology that we live in varies with the imperatives and modes of our production and reproduction; that is whether we appropriate the ecology, as we must do, to sustain livelihoods or as a commodity saleable for profit. The former is socialized appropriation, a necessity of life, the dynamics and characteristics of which are more ecologically sustainable than the latter, capitalist appropriation. This is an avaricious appropriation, the logics and mechanisms of which are inherently destructive to the ecology (Biel 2012; Moore 2015). Socialized appropriation, as observed above, is natural and engaged by humankind across time and space, capitalist appropriation is specific to the capitalist mode of production. Since its emergence in England in the eighteenth century, capitalism is inherently contradictory to 
the sustainable appropriation of the ecology by humankind. It is "largely indifferent to the complexity and continuity of ecological and social structures, and how they may be governed by different rhythms, seasons and social relations from those associated with the capitalist market system" (Gill 2018: 248). Capital sees nature not as a livelihood resource to be appropriated sustainably, but as something to be capitalized; namely, to be commodified and converted to more and more cash (Moore 2015: 160-161). It is not only in normal times that the accumulation imperative and mechanisms of capital are inherently damaging to the ecology. They are even worse during its inherent cyclical crises. In its effort to reinvent itself out of these crises, capital becomes more and more voracious in its "appetite for new frontiers of appropriation" (Moore 2015: 161; see also Biel 2012); thus, engineering ecological imperialism.

The last point is that capital's indifference to the sustainability of the ecology - and the pillage of the ecology that accompanies it - neither distributes the benefits and losses of capitalist accumulation equally between the periphery and the core of the capitalist economy, nor does it do so between classes in both the core and the periphery. So, in addition to the exploitative economic terms by which some regions in the periphery are integrated into the global economy is the unequal ecological exchange between them and those in the core. Both in normal times of accumulation and during its cyclical crises, capital engenders disastrous ecological effects in the periphery: it extracts massive resources from the periphery to the core, and in the process wreaks havoc on the ecosystem through extractive mechanisms such as mining. In addition, the negative effects of its accumulation mechanisms in the core spreads to the periphery through natural forces, or are deliberately channelled there by the deliberate actions of the forces of capitalism, such as the dumping of waste, including e-waste in the periphery. "The Global South countries", Oulu (2016: 447) argues, "thus tend to serve as a source of raw materials and sink for waste products for industrialized countries... Such unequal material-ecological exchanges perpetuate global inequalities and uneven environmental impacts which disproportionately harm the people in developing countries but enhance the productive capacity of the developed." (See also Clark and Foster 2009: 311-312; Martinez-Alier et al. 2016: 468).

All the preceding dynamics of the capitalist global economy interact to configure and drive ecological imperialism; the motor that has driven (and continues to drive) capitalist accumulation since its origins. Even though capitalism emerged in and engendered industrialization in the Western industrialized countries, these developments needed the appropriation of ecosystems outside their spatial confines. They needed land, labor, minerals (silver and gold), food, and other raw materials from Africa, the New World, and beyond. The exploitation of these natural resources, just as the exploitation of minerals and oil in Africa today, wrought implacable ecological destruction. From the onset, therefore, ecological imperialism was critical to capitalism and capitalist development in the core centers of the capitalist world system (Crosby 2004; Moore 2015; Pomeranz 2000). The extent to which capital's appropriation of the ecology of Africa and the New World influenced the development of the core capitalist countries is debatable, but the influence itself is not. As correctly noted by Pomeranz (2000), the pillaging of the ecology of Africa and the New World was not the sole motor of European development, but it provided some of the essential land-intensive resources that Europe lacked but needed to drive its industrial revolution. Britain, the cradle of the industrial revolution, took advantage of the core-periphery relationship of the capitalist world-system to gain "access to some of the landintensive products that all the major Eurasian cores were, by the late eighteenth century, finding it difficult to secure enough of (Pomeranz 2000: 185-86).

Africa has served and continues to serve as part of the 'cheap Nature' that capital appropriates on a world scale for the accumulation of wealth and for reinventing itself out of its cyclical crises (Moore 2015). It seems, therefore, that ecological imperialism - in the way that it is central to capitalist accumulation - will be with Africa for a long time. Large-scale mining by foreign companies represents one of the ligaments of continuity through the history of ecological imperialism in Africa. It is this present-day ecological imperialism in Ghana that we turn to below.

\section{Gold mining and ecological imperialism in Ghana}

As mentioned, mining is inherently a polluting and socially-dislocating industry that lasts several decades or longer after the mine has been decommissioned. There are two major types of mining in Ghana: 
large-scale mining (LSM) and artisanal and small-scale mining (ASM). As discussed in section two, thanks to media biases against the latter and the Ghanaian state's biases in favor of the former, ASM is considered a menace that must be fought and defeated for the good of society. In contrast, LSM is a source of foreign direct investment (FDI) and revenue to the state, so it must be promoted; indeed, it must be motivated with juicy incentives to invest in the country (Ayelazuno 2011: 540). The silences about the environmental ravages of LSM by foreign mining companies are part of the mechanics of ecological imperialism, devised and pursued by an alliance of powerful classes against a powerless fraction of the ASM industry. The powerful classes we have in mind are foreign mining capital, fractions of the Ghanaian state, and fractions of the Ghanaian media. The powerless fraction of the ASM consists of the poor peasants and unemployed who do artisanal mining, either as their main means of income or as part of diverse livelihood strategies.

In the rest of this section, we describe briefly the egregious environmental and social ravages wrought by multinational mining companies on mining communities across Ghana. James Ferguson's description of the horrific situation of Zambian miners in the copper belt after Zambia's independence captures the situation in these communities. He described their situation as "[a]bjection... a process of being thrown aside, expelled, or discarded. But its literal meaning also implies not just being thrown out but being thrown down - thus expulsion but also debasement and humiliation" (Ferguson 1998: 236). A similar situation exists in Ghanaian mining communities where LSM companies operate. As mentioned earlier, human beings are part and parcel of the ecology. They have a symbiotic relationship with the non-human components of the ecology; therefore, any intrusion into this relationship - in the ways LSM companies have done and continue to do in these communities - constitutes one dimension of destruction of the ecology. And in the specific case of LSM companies, this constitutes ecological imperialism.

The material presented and discussed below is gleaned from secondary and primary sources. The former is the prodigious body of literature, scholarly and grey, describing and analyzing foreign mining companies and mining communities in Ghana (see for example, Akabzaa 2000; Akabzaa and Darimani 2001; Andrews 2018, 2019; Ayelazuno 2011, 2014; CHRAJ 2008; Human Rights Clinic 2010; Ismi 2003; WACAM 2016; Wan 2014). The primary source is based on ethnographic work we did in four mining communities in the Western region; Bondaye, Prestea, Dumasi, and Teberebi in the Prestea-Huni Valley and Tarkwa Nsuaem Municipalities. This work was done in 2008 and 2016, using data-collection strategies such as nonparticipatory observation, key informant interviews (KII), and focus groups discussion (FGD). Through these methods we gained firsthand information on the ecological and social ravages wrought by large-scale mining on the inhabitants of communities staying close to the mines.

\section{Ravages of LSM on the ecology in Ghana: degradation of land, vegetative cover and livelihoods}

Land and other natural resources support mining communities in Ghana. They also constitute the bedrock of the production and reproduction of peasants, artisanal miners and all other segments of the rural populace who live from them. The inhabitants of these communities appropriate land and its resources for various livelihood activities such as hunting and gathering, farming staples such as maize, plantain, cassava, coco yam, and palm-nut, depending on their position in Ghana's north-south rainfall gradient. The forest also provides women's firewood, the main source of fuel for cooking; and also provides mushrooms and snails, some of the basic foodstuffs women obtain from the forest to cook various local dishes. Just as their ancestors have done before them, some of them also engage in artisanal mining, diversifying away from dependence on farming and hunting. The inhabitants of mining communities conserve their ecosystem - which they know they are a constituent part - through various believes and practices, including recycling the waste from their consumption into enriching the fertility of the soil. In most traditional Ghanaian societies, people believe that nature and their socioeconomic lives and activities are organically connected; thus, there are myriad practices and beliefs that aim to preserve it for the present and future generations (Asante et al. 2017; Sarfo-Mensah and Oduro 2007).

The implementation of structural adjustment programmes (SAPs) in the 1980s resulted in what could be described as the 'new' gold rush in Ghana, given that these reforms resulted in the liberalization of the mining sector with stupendous flows of foreign direct investment (FDI) into gold mining (Hilson and Potter 2005:107; 
Hilson and Yakovleva 2007: 101). Large tracts of land are the direct targets for acquisition by multinational and foreign mining companies entering the sector (Andrews 2019; Ayelazuno 2011). This is because of the use of surface mining technology, a mode of mining that, unlike traditional deep shaft and underground mining, requires a lot of land (Schueler et al. 2011). The mining companies prefer surface mining because it is more profitable. Daniels (2018) offers three reasons for this: it is cheaper, safer, and mechanically easier to operate than underground mining. It requires less human labor and equipment, and more gold can be extracted in a short period of time. It is safer because it doesn't involve workers going underground, lessening or eliminating the dangers of exposure to explosives, and death from mine accidents such as cave-ins. Mechanically, surface mining is easier to operate because heavy equipment and vehicles can move freely to mine and process gold; drilling, blasting, loading and hauling (Ramani 2012).

Though profitable, surface mining ravages mining communities, socially and environmentally (Palmer et al. 2010). The processes involved create their social and environmental dislocation, not least through creating mining waste. According to one authoritative source, out of "the over 30 billion tonnes of ore and waste materials that are mined each year, surface mining accounts for nearly 25 billion tonnes" (Ramani 2012: 9). Mining concessions include the core mining and processing activities, but also huge waste dumps.

There are various estimates of the extent of mining concessions. According to one source, one third of the Western Region of Ghana and 60\% of the Wassa West District are estimated to be under concession to large-scale mining companies (Aubynn, cited in Banchirigah, 2006: 168). Drawing on various sources, Banchirigah (2008: 30) offers us the following details:

- By 2006, about $31,237 \mathrm{~km}^{2}$ or $13.1 \%$ of Ghana's landmass was estimated to be under concession to mining and mineral exploration companies;

- About $70 \%$ of the land of Tarkwa and two thirds of the $2,578 \mathrm{~km}^{2}$ land of Wassa West District form part of the above-mentioned mining concession;

- Gold Fields, one of the mining companies operating in the above-mentioned district had a mining concession of $204 \mathrm{~km}^{2}$ in Tarkwa and $49 \mathrm{~km}^{2}$ in Damang;

- Golden Star Resources Ltd.'s mining concession is made of $145 \mathrm{~km}^{2}$ in Bogoso and $129 \mathrm{~km}^{2}$ in Prestea (see also Hilson and Potter 2005: 120-123).

Beyond the Western Region, the empirical referent of this article, the story seems similar. Newmont Ghana Gold Limited operates in the Ahafo Kenyasi and surrounding areas in the Brong Ahafo region. The company's mining concession is substantial, and it has an existing population. "The Ahafo mine", Andrews (2018: 243) informs us, "involves $774 \mathrm{~km}^{2}$ of land covered by mining and prospecting licenses and $834 \mathrm{~km}^{2}$ of land covered by reconnaissance licenses, together with an approximate $48 \mathrm{~km}$ strike length. The total mining lease area contains 10 primary communities with a total of approximately 208,000 inhabitants, most of whom are supported by subsistence farming."

What is unjust about these concessions is that, whilst the inhabitants of these mining communities are expropriated of their main source of livelihoods, their lands are used as waste dumps. About fifty per cent of the land is often not used "for actual mining", but for "dumps, workshops, warehouse etc." (Aryeetey et al. 2004: 32). Little wonder, therefore, that these inhabitants, as our fieldwork reveals, complain angrily about the failure of the government to intervene to address the deleterious environmental and social effects inflicted on them by LSM. During our fieldwork we observed first-hand the expropriation of land from the people of Bondaye, Prestea, Dumasi, and Teberebi. In addition, we heard the inhabitants describe vividly the environmental and social injustices they have suffered from the activities of the multinational and foreign mining companies. These injustices include land seizures, loss of their farms and food, environmental/water pollution, and strange illnesses. In Bondaye, we observed the massive clearing of land cover by Golden Star Resources Ltd., the mining company that operates in this community (see Figure 1).

Participants of our FGDs in this community spoke about the impact of large-scale mining (LSM) activities on their living conditions. Most of them, especially youth, said they engage in both artisanal mining and small-scale farming for a living, but their livelihoods are now in jeopardy because foreign mining 
companies have taken over their lands. A male participant who was visibly angry about the disruption of their livelihood activities by the mining companies said;

In Ghana they [the government] shouldn't allow surface mining. They [mining companies] have to do deep mining......the surface mining spoils our land. It spoils our farms. It is not easy for us here at all. If the government [of Ghana] looks on whilst they [mining companies] spoil the land that we farm on to feed ourselves, what do we do to stay alive and go to vote for them during elections for them to come to power? We don't like the surface mining at all. (FGD in Bondaye, Western Region, 20 April 2016)

The views expressed here in Bondaye in 2016 are strikingly similar to those expressed in 2008 by the participants of our FGDs in the neighboring mining communities of Teberebi, Dumasi, and Prestea. For example, the women participants of our FGD in Teberebi complained about the seizure their farm lands by the mining companies, constricting their access to land for farming their food staples. Pointing at a mountain of waste dump close to their village (see Figure 2), this is what one woman-peasant said:

That is where the mines are and all that is their waste occupying our farms. The waste has taken over our farms and we now have to walk long distances to farm on the land not yet affected by the waste. This has made cassava very expensive. (FGD in Teberebi, Western Region, 21 November 2008)

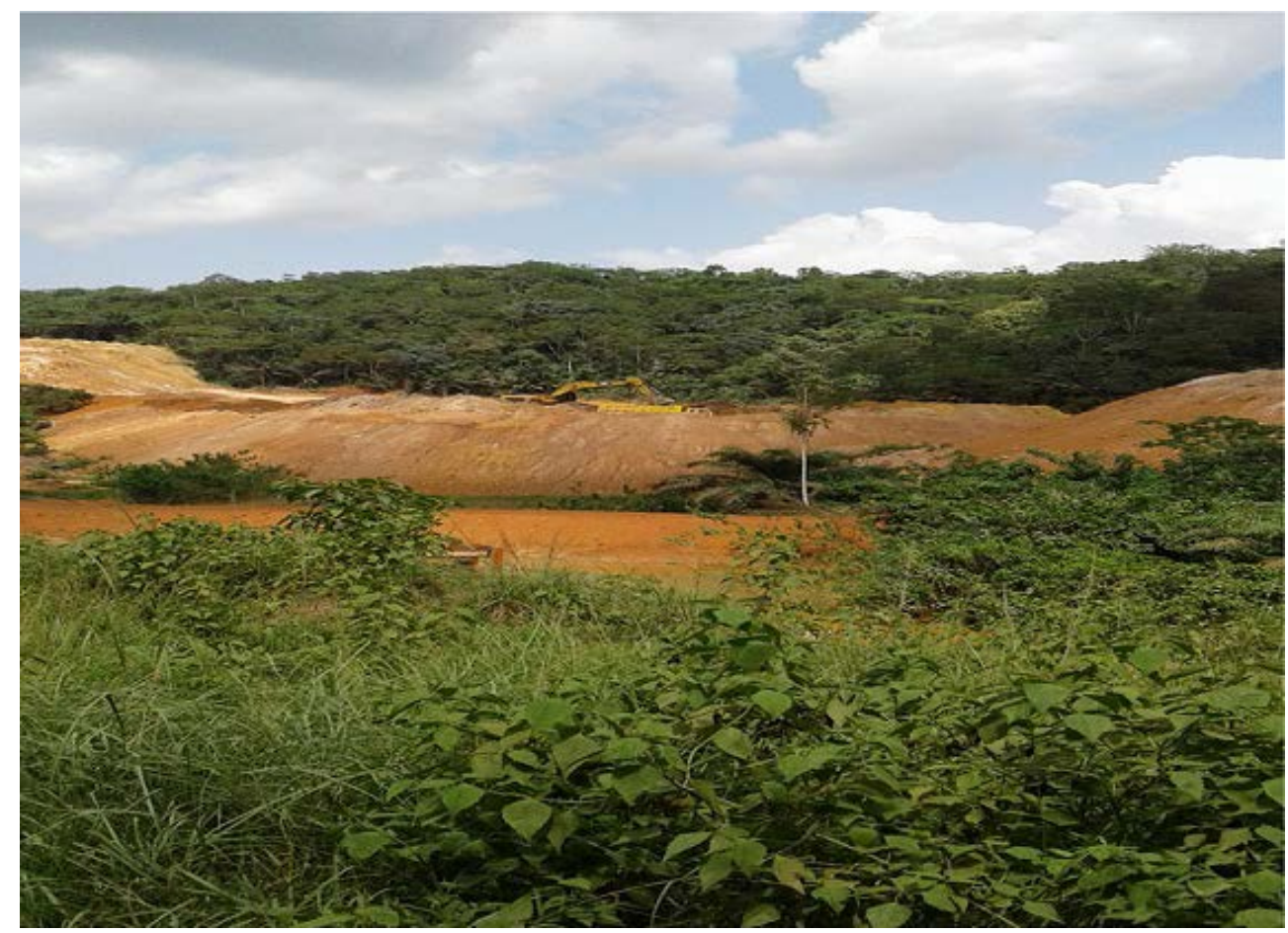

Figure 1: Land degradation by LSM in Bondaye.

We were told similar stories in 2016 when we went back to the same community for our follow-up fieldwork. Even though we interviewed a different set of respondents, they complained about the same injustices by the mining companies. For example, they complained about the lack of access to their farmlands, and environmental pollution. When participants of our FGD were asked whether there had been any improvements 
to their living conditions over the last eight years (since our first fieldwork), one male participant said "our conditions have not improved." He continued:

Concerning farming, we still walk long distances. Today, if a car has to take you to the farm, you will pay 15 cedis [about US\$3] to the farm and 15 cedis to return home. A total of 30 cedis [approximately US\$6). Anything you are bringing from the farm, for example, firewood and other things, you have to pay for the car to bring them. It has made our going to farm very, very difficult for us. There is no way we can farm. The land closer to us that we could have used for farming has been confiscated from us to be used for waste dumps and other things. They are even trying to relocate us from this village to somewhere further forward ... Some houses have been marked [for demolishing]. We don't know whether we are going to be living here in the near future or they will be relocating us somewhere else. Our stay in this village is shaky. (FGD in Teberebi, Western Region, 20 April 2016)

With remote sensing, the assessment and tracking of land cover change from surface mining can be done with more accuracy. Schueler et al.'s (2011) study illustrates graphically and quantitatively the seriousness of these problems in three mining concessions within and near our study area: Damang, Bogoso-Prestea, and Tarkwa. They show massive and rapid change to the land cover in all the three areas. Schueler et al. emphasize "Gold mining in Wassa West District resulted in widespread land cover change between 1986 and 2002 in all threemining concession that we studied...Our satellite-based analyses confirmed that conversions from forest and farmland to mining pits were the two most widespread land cover changes" (2011: 533-534). The mutual relationship between the people of mining communities and their ecology has clearly been disrupted by the activities of LSM.

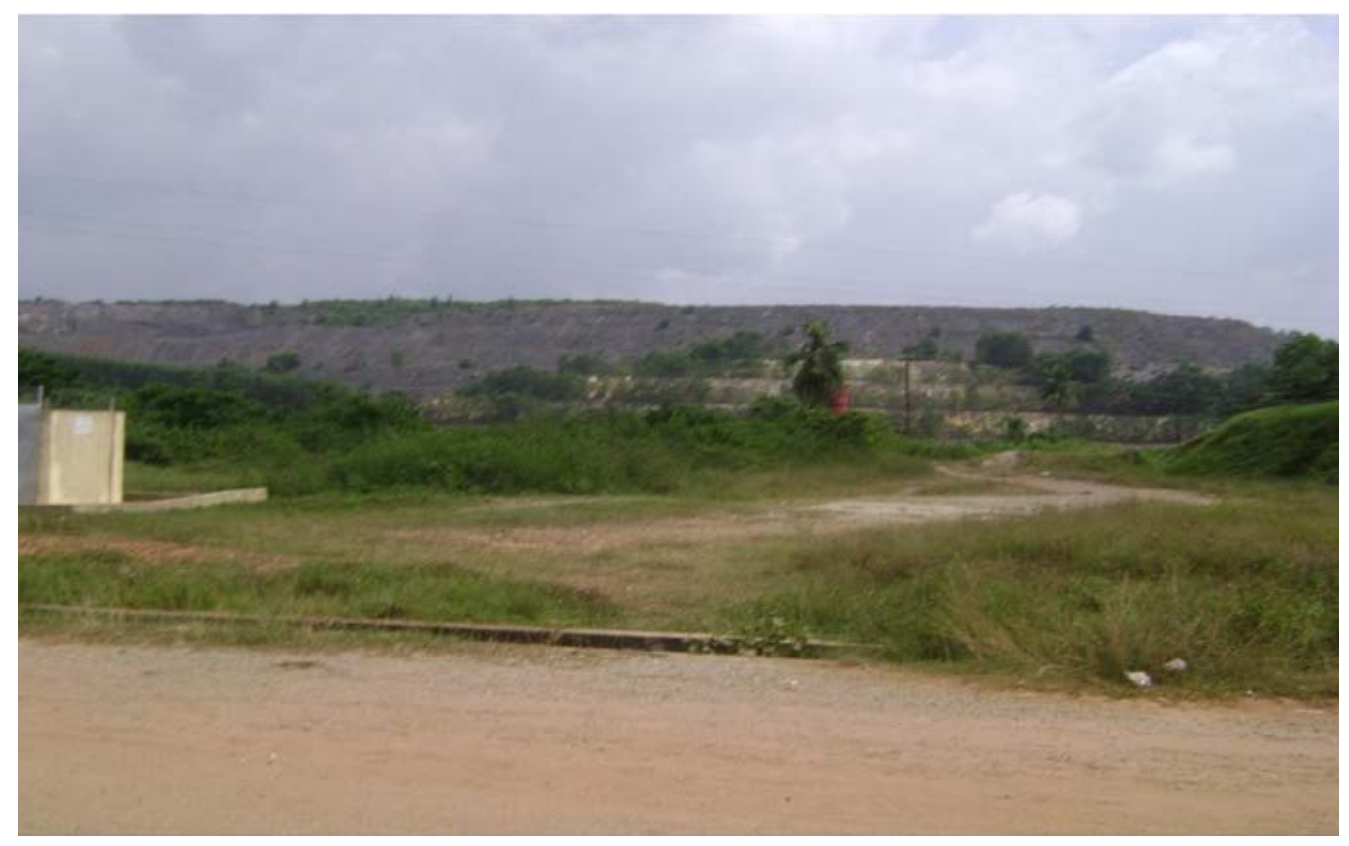

Figure 2: Land degradation in Teberebie and Prestea. 


\section{Ravages of LSM on the ecology in Ghana: pollution of streams and acute shortage of water}

Water is life. "Not having access to water and sanitation is a polite euphemism for a form of deprivation that threatens life, destroys opportunity and undermines human dignity" (UNDP 2006: 5, cited in Agnew and Woodhouse 2011). Yet access to potable drinking water in Ghana is a serious problem for a significant number of Ghanaians, even in the cities, including Accra, the national capital. The problem is worse in the rural areas where there is no piped water, despite streams and rivers passing through most villages. Indeed, one of the major factors that determine the location of villages is access to water. Communities cluster along rivers and water bodies. Village names are usually those of the adjacent stream or river, such as Huniso, Subriso, and Praso and indeed where we conducted fieldwork (Obiri 2009). Water courses are used for drinking, cooking, washing, fishing, even when there may be some health risks.

To reemphasize, mining of all forms and scales - whether large- medium- or small-scale, legal or illegal - pollutes the fresh water sources of local communities. A lot of water and chemicals are used to process gold bearing ore. Because of this, water has been called "mining's most common casualty" (Safe Drinking Water Foundation [SWDF] n.d). The use and discharge of water and chemicals such as cyanide and mercury, as well as seepages from the tailings and mining waste, poison freshwater sources (Aboka et al. 2018; Bawua and Owusu 2018; Bell et al. 2006; Hadzi et al. 2015; SWDF n.d;). In their chase for more profits in Ghana, foreign mining companies take advantage of the institutional deficiencies and loopholes in environmental regulations - as well as the inefficient enforcement of these laws - to discharge this toxic brew into rivers and streams (Armah et al. 2011: 196-198; Aboka et al. 2018: 45). The specific ways by which the mining companies in Ghana pollute water bodies and sources have been summarized by Obiri (2009);

- The mining process exposes heavy metals and sulphur compounds that were previously locked away in the earth. Rainwater leaches these compounds out of the exposed earth, resulting in "acid mine drainage" and heavy metal pollution that continues long after the mining operations have ceased.

- Similarly, the action of rainwater on piles of mining waste (tailings) transfers pollution to freshwater supplies.

- In the case of gold mining, cyanide is intentionally poured on piles of mined rock (a leach heap) to chemically extract the gold from the ore. Some of the cyanide ultimately finds its way into nearby water bodies.

- Huge pools of mining waste "tailings" are often stored behind containment dams. Most tailings impoundments leak at some point in the mine's life.

There are disastrous human-health consequences from all these for inhabitants of mining communities; because the effluent discharged may lead to heavy metal pollution of water and soil (Ato et al. 2010). And if the presence of heavy metals is above World Health Organization acceptable levels, it can cause cancer or other life-threatening illnesses when ingested through the consumption of affected water or eating food grown on affected soil (see Aboka et al. 2018).

In light of all these potential dangers of surface mining, the gold rush in Ghana was bound to rob the inhabitants of mining communities their gifts of nature: the springs, streams, the rivers and their tributaries; and ultimately, their lives and good health. And together with them fish, crabs, lobsters, aquatic insects, aquatic vegetation and many other amphibians (Amegbey and Adimado 2003). The rivers, their, tributaries, and streams have been polluted by the discharge of dangerous effluents and chemicals (such as cyanide) from the open pit mines dug by foreign mining companies. Cyanide spillages from large-scale mining is a clear danger linked to gold processing (Amegbey and Adimado 2003). If not well-managed and controlled properly, cyanide can easily end up in the environment. Because of the institutional deficiencies of Ghanaian mining regulatory agencies, mining companies have been reckless and negligent in the management and control of the use of cyanide. Cyanide spillages have been well documented in Ghana, the major ones reported by Amegbey and 
Adimado (2003), Ismi (2003); Armah et al. (2011: 196); WACAM (http://www.wacamghana.org/), Mines and Communities (http://www.minesandcommunities.org/); and the Ghanaian media portals. They include:

1. The Obenemase Mine (OM), near Konongo, spilled cyanide into the environment in 1989 and contaminated a tributary of the Owerri River;

2. In 1990, Obenemase Mines near Konongo spilled large quantities of cyanide solution, which contaminated a tributary of the River Oweri;

3. In 1994, the Bogoso Gold Limited (BGL) spilled large volumes of cyanide into the River Anikoko, which flows into the River Bodwire;

4. In June 1996, a spill at Teberebie Goldfields sent 36 million litres of cyanide solution into the Angonaben stream, a tributary of the Bonsa River;

5. In October 2001, a tailings dam at Tarkwa burst sending thousands of cubic metres of mine wastewater into the Asuman River contaminating it with cyanide and heavy metals;

6. On 23 October 2004, Bogoso Gold Limited (BGL) again spilled cyanide into the River Aprepre, which flows into other rivers, including Egya Nsiah, Bemanyah, Manse and Ankobra;

7. In June 2006, The Bogoso Gold Limited (BGL) spilled cyanide into the Ajoo stream, which flow into the big river Ankobra.

8. On 10th October 2009, Ahafo Mine of Newmont Ghana Gold Limited (NGGL) spilled large volumes of cyanide solutions into the Asunua and Subri rivers in the catchment area and killed fish and other aquatic organisms.

9. On $7^{\text {th }}$ August 2012, NGGL was again blamed by the Centre for Environmental Impact Assessment (CEIA) for cyanide spillage which CEIA established scientifically to be the cause of the death of 3,000 fish found floating on the Subri river dam at Damso, near NGGL Ahafo Mine site. NGGL pleads innocence but proven scientifically and by the above pattern of cyanide spillage (Ghana News Agency 2012).

Cyanide is noted as "among the most harmful substances on Earth" (Kwaansa-Ansah et al. 2017: 1). Similar to heavy metal pollution, cyanide is one of the most lethal threats to the human health of mining communities as people in these communities can ingest it through eating contaminated tubers like cassava and cocoyam; drinking contaminated water and eating contaminated fish; through dermal contact; and through breathing contaminated air. Kwaansa-Ansah et al. (2017) did an experimental study on the levels of cyanide contamination of tubers, water, and fish in Kenyasi, the community in which the Ahafo Mine of NGGL is located. The results show that the levels of cyanide in the samples taken from areas close to the mine were dangerously higher than those taken from non-mining areas. The study concluded that the "daily intake of total cyanide for both adult and children via cassava and cocoyam consumption were considerably higher than the provisional tolerable daily intake values. Therefore, the persistent intake of cassava and cocoyam can probably induce adverse health effects" (Kwaansa-Ansah et al. 2017: 9).

Against this background, it is unsurprising that, both in 2008 and 2016, the common thread that ran through our FGDs and KIIs is that the mining companies have "killed their streams" or that their "streams are dying." According to one key informant, the six streams that used to serve as a source of drinking water to his village (Dumasi) have "died" from the chemicals discharged into them by the mining companies (KII in Dumasi, Western Region, 21 November 2008). Eight years later, this story had not changed; which means water quality has not improved. Participants of our FGD in Bondaye complained of the acute water shortage they were facing because of the "death" of their streams. One of them said, "the mining waste and chemicals have spoilt our water...they have killed our streams" (FGD in Bondaye, Western Region, 20 April 2016).

In addition to their streams, the people of Prestea used to be blessed with spring water, from which they obtained freshwater. By some accounts, there were seven springs; among which the Railway spring provided 
the people of Prestea with natural groundwater for drinking and other domestic purposes (Varris and Thorpe 2012; Myjoyonline.com 20 October 2015). Surface mining by Golden Star Resources Ltd has either polluted or damaged this gift and beauty of nature. One of the company's surface mining pits, the Plant North pit, sits in the Asuo Kofi river valley. The waste generated by the development of this pit has been dumped on the Railway spring, damaging and disrupting the local ecosystem (Varris and Thorpe 2012; Mines and Communities 2013). Besides the Railway Spring, four tributaries of the Ankobra River pass through Prestea and its surrounding areas, serving as another source of fresh water. These sources have all been exposed to pollution from the Plant North pit which discharged its waste into the Asuo Kofi River and the Ankobra River (Varris and Thorpe 2012: 656).

The cumulative effect of all the pollution and "deaths" of rivers and streams in the mining communities we studied is acute shortage of water. Women complain of the long distances they have to walk to the nearest unpolluted stream to fetch water. In all the communities - Bondaye, Teberebi, Dumasi, and Prestea - the inhabitants complain that they cannot get water to drink and for other domestic purposes. Those who can afford it, usually buy purified water, popularly called "sachet water" in Ghana; and those who cannot, drink whatever water they can get, regardless of the pollution in all the ways described above. Figure 3 captures the acute water situation in Bondaye, with women standing in long queues to fetch water from the only house with a water tap. As part of their corporate social responsibility (CSR), Golden Star Ltd. uses water-tanker vehicles to supply water to the communities in their "catchment area."
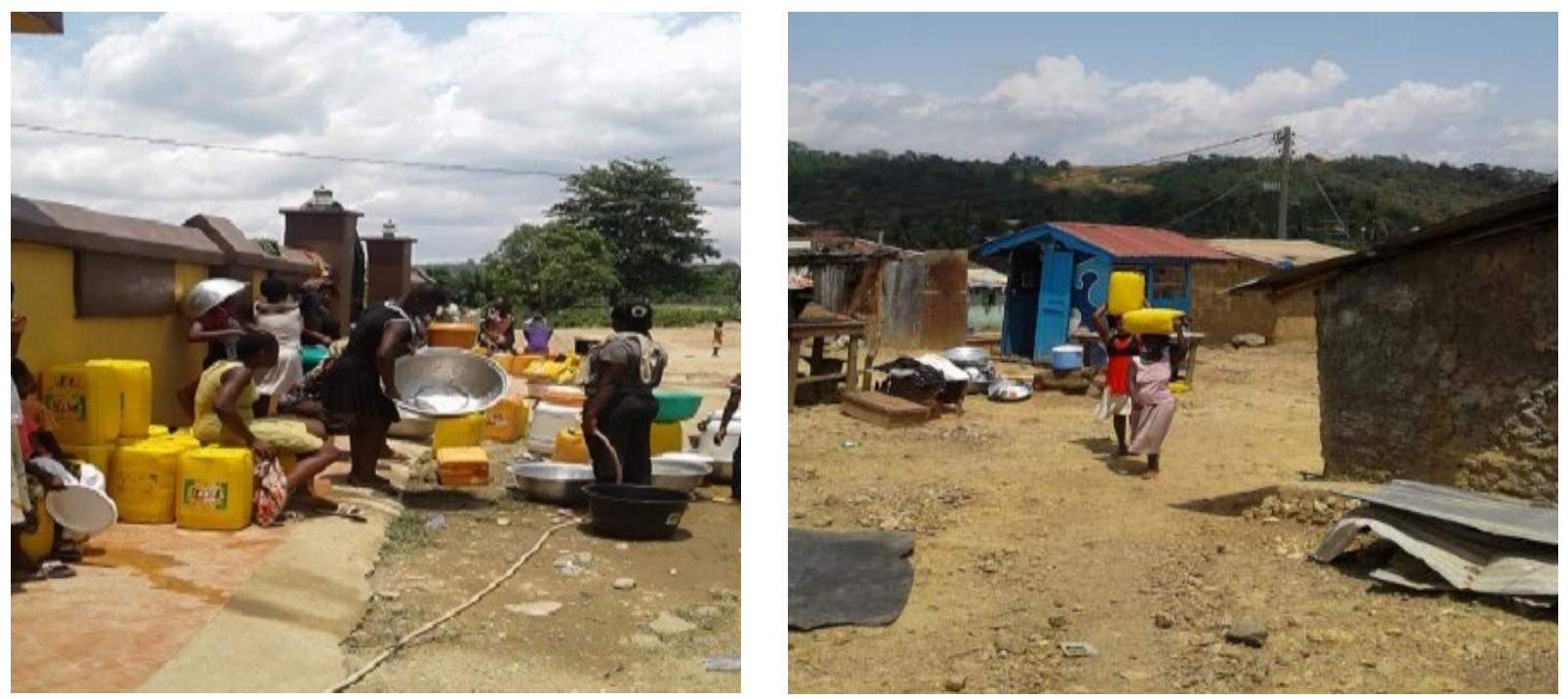

Figure 3: Women in Bondaye fetching and carrying water from the only house with tap water.

Figure 4 shows water-tanker vehicles supplying water to inhabitants of Dumasi and Bondaye. However, the inhabitants informed us that the water supplied by the company is not potable. The litmus test, according to the inhabitants, is the color their cassava and plantain take when water is used for cooking. The cassava or plantain turn black, rather than the normal white, peach or yellow. The black color of the food, they assume from their common-sense science, shows that the water is polluted with the poisonous chemicals used by the mining companies to process gold. This assumption, though, not based on any modern scientific test, may not be totally erroneous, considering the pollution of water sources documented above. 


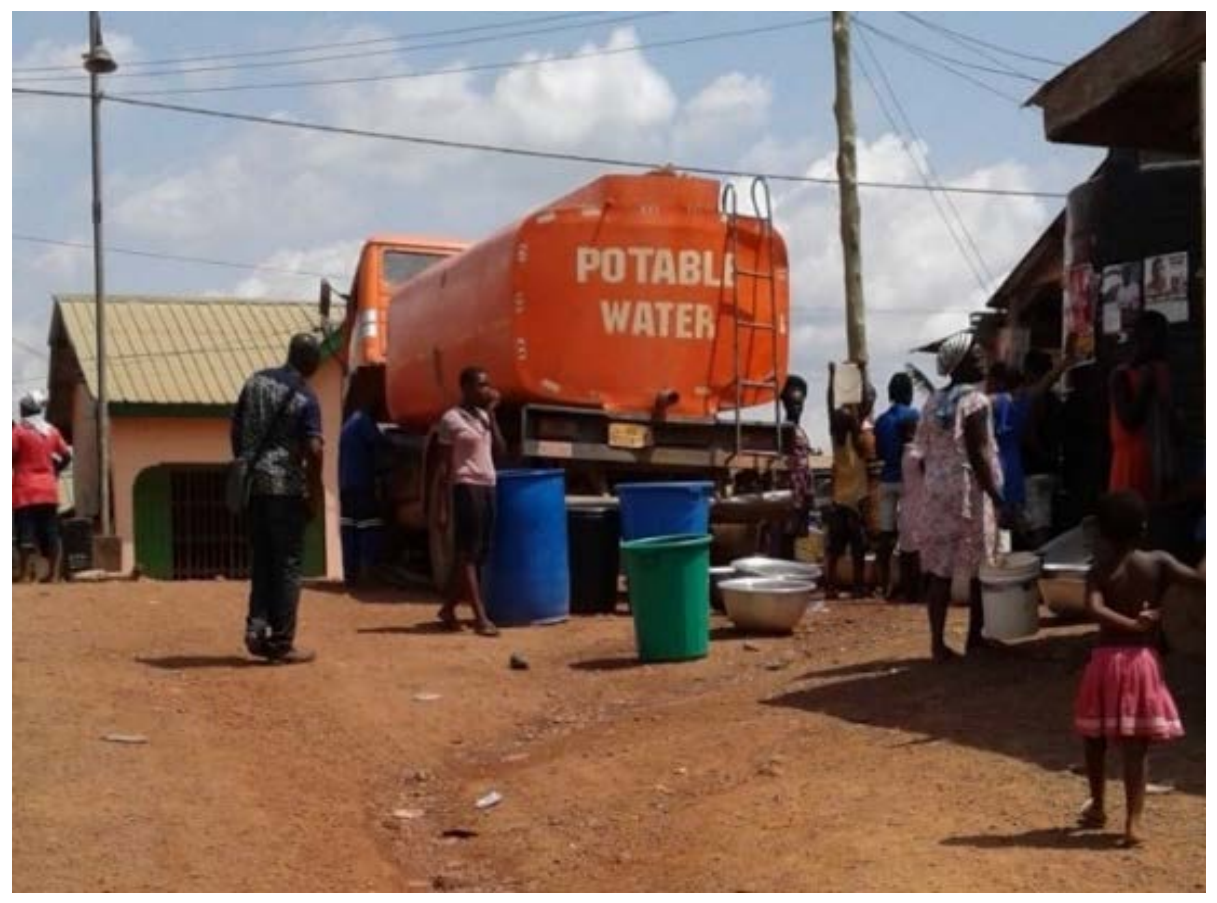

Figure 4: Water-tanker vehicles supplying Dumasi and Bondaye.

\section{Concluding remarks}

Foreign mining companies are cajoled by the Ghanaian state with juicy incentives to invest in largescale mining of gold because they are viewed as the main source of foreign direct investment (FDI) in the country. Yet LSM, especially in its present surface mining form, has wrought havoc on the ecosystem and livelihoods of mining communities. Enjoying impunity, these companies continue their operations with little interference by the state. Paradoxically, artisanal and small-scale mining (ASM) engaged by the subaltern groups for survival has been constructed and vilified as an environmental and social menace which must be fought with all the coercive apparatuses of the state, including the military. We have argued that the strongarm measures the Ghanaian state has adopted against ASM, ostensibly, to protect the ecology, is in direct contrast to its silences over the rapacious ecological effects large-scale of LSM by these companies. The biases of the Ghanaian state in favor of large-scale mining is based on the romanticization of foreign mining companies as a source of foreign direct investment (FDI), considered as a driver of economic growth and development.

In contrast to the position of the government of Ghana and other advocates of LSM, we argued that, far from promoting development, mining-FDI is a vector of ecological imperialism in Ghana. Ecological imperialism has a long history in Africa, of which the extraction of natural resources by extractive capitals constitutes one of the chief drivers. We have established the continuity of ecological imperialism in the presentday neoliberal world order by documenting the ecological ravages of LSM in Ghana.

We have used the underutilized insights of political ecology, specifically, ecological imperialism, to make sense of the voluminous body of literature on the negative environmental and human effects of largescale mining in Ghana. A great deal of this oeuvre is empiricist and weak in theoretical framing. Our article set out to clarify why LSM companies are treated with kid gloves on one hand, while on the other, Ghanaian subalterns engaged in ASM for survival suffer violence from their own state, including the governments they have voted for to take decisions on their behalf and represent their interests. By drawing on the perspectives of political ecology we have unpicked this paradoxical behavior. Paradoxical at first sight, but only at first sight. 
Further research into mining and the politics of environmental protection in Ghana is needed, drawing on complementary perspectives such as ecological imperialism, social metabolism, ecological unequal exchange, and environmental justice. The political ecology of the harmful impacts of mining on the ecology of Ghana illustrates the concerns over, and the actions and inactions issuing from mining, are neither class-neutral nor free of politics. They are highly politicized and imbricated in power structures and relations. In simple terms, this means the interests of the ruling class rule supreme in the enforcement of environmental laws in the mining sector by the government of Ghana.

\section{References}

Aboka, Y.E., S.J. Cobbina and A.D. Doke. 2018. Review of environmental and health impacts of mining in Ghana. Journal of Health and Pollution 8(17): 43-52.

Akabzaa, T. 2000. Boom and dislocation; the environmental and social impacts of mining in the Wassa west district of Ghana. Third World Network.

Akabzaa, T. and A. Darimani. 2001. Impact of mining sector investment in Ghana: a study of the Tarkwa mining region. Draft report prepared for SAPRI.

Agnew, C. and P. Woodhouse. 2011. Water resources and development. London: Routledge.

Andrews, N. 2015. Digging for survival and/or justice? The drivers of illegal mining activities in Western Ghana. Africa Today 62(2): 3-24.

Andrews, N. 2018. Land versus livelihoods: community perspectives on dispossession and marginalization in Ghana's mining sector. Resources Policy 58: 240-249.

Andrews, N. 2019. Gold mining and the discourses of Corporate Social Responsibility in Ghana. New York: Palgrave Macmillan.

Amegbey, N.A. and A.A. Adimado. 2003. Technical note: incidents of cyanide spillage in Ghana. Mineral Processing and Extractive Metallurgy 112: 126-130.

Armah, F.A., S. Obiri, D.O. Yawson, E.K.A. Afrifa, G.T. Yengoh, J.A. Olsson and J.O. Odoi. 2011. Assessment of legal framework for corporate environmental behaviour and perceptions of residents in mining communities in Ghana. Journal of Environmental Planning and Management 54(2): 193-209.

Asamoah, K. and A. Osei-Kojo. 2016. A contextual analysis of implementation challenges of small-scale mining laws in Ghana: a case study of Bekwai Municipality. SAGE Open July-September: 1-11.

Asante, E.A., S. Ababio and K.B. Boadu. 2017. The use of indigenous cultural practices by the Ashantis for the conservation of forests in Ghana. SAGE Open January-March: 1-7.

Ato, A.F., S. Obiri, Y.D. Oscar and P.A. Nii Moi. 2010. Mining and heavy metal pollution: assessment of aquatic environments in Tarkwa (Ghana) using multivariate statistical analysis. Journal of Environmental Statistics 1(4): 1-13.

Ayelazuno, J. 2011. Continuous primitive accumulation in Ghana: the real-life stories of dispossessed peasants in three mining communities. Review of African Political Economy 38(130): 537-550.

Ayelazuno, J. 2014. Oil wealth and the well-being of the subaltern classes in Sub-Saharan Africa: a critical analysis of the resource curse in Ghana. Resources Policy 40: 66-73.

Banchirigah, M.S. 2006. How have reforms fuelled the expansion of artisanal mining? Evidence from subSaharan Africa. Resources Policy 31(3): 165-171.

Banchirigah, M.S. 2008. Challenges with eradicating illegal mining in Ghana: a perspective from the grassroots. Resources Policy 33(1): 29-38.

Bawua, S.A. and R. Owusu 2018. Analyzing the effect of Akoben programme on the environmental performance of mining in Ghana: a case study of a gold mining company. Journal of Sustainable Mining 17: 11-19.

Bell, F.G. and L.J. Donnelly. 2006. Mining and its impact on the environment. London: Spon Press.

Biel, R. 2012. The entropy of capitalism. Leiden: Brill. 
Citifmonline. 2018. Operation Vanguard boss laments 'slow' prosecution of 'galamseyers' 31 January 2018 https://www.ghanamma.net/2018/01/31/operation-vanguard-boss-laments-slow-prosecution-ofgalamseyers/

Commission on Human Rights and Administrative Justice (CHRAJ). 2008. Study on the state of human rights in mining communities in Ghana. Accra: CHRAJ.

Clark, B. and J.B. Foster. 2009. Ecological imperialism and the global metabolic rift unequal exchange and the guano/nitrates trade. International Journal of Comparative Sociology 50(3-4): 311-334.

Crawford, G., C. Agyeyomah, G. Botchwey and A. Mba. 2015. The impact of Chinese involvement in smallscale gold mining in Ghana. London: International Growth Centre (IGC).

Crawford, G. and G. Botchwey. 2018. Militarisation and criminalisation of artisanal and smallscale gold mining: the state and the so-called 'galamsey menace' in Ghana. Review of African Political Economy 45(156): 321-334.

Crosby, A.W. 2004. Ecological imperialism: the biological expansion of Europe, 900-1900. Cambridge: Cambridge University Press.

Daniels, R. 2018. The advantages of open pit mining. sciencing.com, June 15, 2018 https://sciencing.com/advantages-open-pit-mining-7218839.html

Domfeh, K.A. 2003. Compliance and enforcement in environmental management: a case of mining in Ghana. Environmental Practice 5(2): 154-165.

Ferguson, J. 1998. Expectations of modernity: myths and meanings of urban life on the Zambian Copperbelt. Berkeley: University of California Press.

Ferguson, J. 2005. Seeing like an oil company: space, security, and global capital in neoliberal Africa. American Anthropologist 107(3): 377-382.

Ghanaweb.com. 2017. Galamsey tapes out, Ghanaweb.com, May $12, \quad 2017$. https://www.ghanaweb.com/GhanaHomePage/NewsArchive/Galamsey-sex-tapes-out-537116

Ghanaweb.com. 2018. Galamsey is still on the rise in forest reserves - Kenneth Ashigbey, Ghanaweb.com, December 13, 2018. https://www.ghanaweb.com/GhanaHomePage/NewsArchive/Galamsey-is-stillon-the-rise-in-forest-reserves-Kenneth-Ashigbey-708590

Ghanaweb.com. 2019a. Osafo Maafo justifies why galamsey Queen Aisha Huang was 'freed', Ghanaweb.com, April 17 2019. https://www.ghanaweb.com/GhanaHomePage/NewsArchive/Osafo-Maafo-justifieswhy-galamsey-Queen-Aisha-Huang-was-freed-739234

Ghanaweb.com. 2019b. Galamsey fight can collapse - Kweku Baako warns. Ghanaweb.com, April 25, 2019 https://www.ghanaweb.com/GhanaHomePage/NewsArchive/Galamsey-fight-can-collapse-KwekuBaako-warns-741193

Ghana News Agency (GNA). 2012. Fish-kill at Newmont Ahafo Mine due to cyanide spillage - CEIA. August 7, 2012. http://www.ghananewsagency.org/social/fish-kill-at-newmont-ahafo-mine-due-to-cyanidespillage-ceia-47411

Gill, S. 2018. Organic crisis, global leadership and progressive alternatives. In S. Gill (ed.) Global crises and the crisis of global leadership. Cambridge: Cambridge University Press. Pp. 233-254.

Graphic Online/Isaac Yeboah. 2018. Operation Vanguard in numbers: the story so far, Graphic Online, Feb 21. https://www.graphic.com.gh/news/general-news/operation-vanguard-in-numbers-the-story-sofar.html

Graphic Online. 2019a. Two MPs sue 35 mining companies for breaching Ghana's laws, Graphic Online, Jan 14. https://www.graphic.com.gh/news/general-news/ghana-news-2-mps-sue-35-mining-companiesfor-breaching-ghana-s-laws.html

Graphic Online. 2019b. Galamsey: Operation Vanguard rounds up 50 suspects, Graphic Online, May 15. https:/www.graphic.com.gh/news/general-news/galamsey-operation-vanguard-rounds-up-50suspects.html) 
Hadzi, G. Y., D.K. Essumang and J.K. Adjei. 2015. Distribution and risk assessment of heavy metals in surface water from pristine environments and major mining areas in Ghana. Review of Environmental and Health 5(9): 86-99.

Hilson. G. 2017. Shootings and burning excavators: some rapid reflections on the Government of Ghana's handling of the informal Galamsey mining 'menace'. Resources Policy 54: 109-116.

Hilson, G. and A. Hilson. 2017. Mining in Ghana critical reflections on a turbulent past and uncertain future. In E. Aryeetey and R. Kanbur (eds.). The economy of Ghana sixty years after independence. Oxford: Oxford University Press. Pp. 260-276.

Hilson, G. and C. Porter. 2005. Structural adjustment and subsistence industry: artisanal gold mining in Ghana. Development and Change 36(1): 103-131.

Hilson. G. and N. Yakovleva. 2007. Strained relations: a critical analysis of the mining conflict in Prestea, Ghana. Political Geography 26: 98-119.

Hira, A. and J. Busumtwi-Sam. 2018. Mining community benefits in Ghana: a case of unrealized potential. A project funded by the Canadian International Resources and Development Institute.

Hopkins, T.K. and I. Wallerstein. 1972. World-Systems analysis: theory and methodology. Beverley Hills: SAGE.

Human Rights Clinic. 2010. The cost of gold: communities affected by mining in the Tarkwa region of Ghana. Texas: University of Texas School of Law.

Ismi, A. 2003. Canadian mining companies set to destroy Ghana's forest reserves. Ontario: Canadian Centre for Policy Alternatives Monitor.

Johnson, A.W. and T. Earle. 2000. The evolution of human societies: from foraging group to agrarian state. Stanford: Stanford University Press.

Kwaansa-Ansah, E.E., P.L. Amenorfe, E. Armah and F. Opoku. 2017. Human health risk assessment of cyanide levels in water and tuber crops from Kenyasi, a mining community in the Brong Ahafo Region of Ghana. International Journal of Food Contamination 4(16): 1-13.

Mines and Communities (MAC). 2013. Ghana: residents of Prestea \& Himan attacked by Golden Star security, police, and military. June 16. http://www.minesandcommunities.org/article.php?a=12433

Mines and Communities (MAC). 2018. The mines and communities website, June 18, 2018 http://www.minesandcommunities.org/.

Marx K. 1976[1867]. Capital: a critique of political economy. Vol. 1. London: Penguin Harmondsworth.

Martinez-Alier, J., F. Demaria, L. Temper and M. Walter. 2016. Changing social metabolism and environmental conflicts in India and South America. Journal of Political Ecology 23: 467-491.

Moore, J.W. 2015. Capitalism in the web of life: ecology and the accumulation of capital. London: Verso.

Myjoyonline.com. 2015. Prestea residents want surface mining halted. Myjoyonline.com, June 16. https://www.myjoyonline.com/news/2015/October-20th/prestea-residents-want-surface-mininghalted.php

Myjoyonline TV. n.d. Kweku Baako reveals blackmail by female Chinese galamsey kingpin. June $24,2019$. https://www.youtube.com/watch?v=ml2pPtVH_x8

Obiri, S. 2009. Determination of heavy metals in water bodies in the Tarkwa and Obuasi mining areas. WACAM, June 26, 2018 http://www.wacamghana.org/researches-and-reports/

Oulu, M. 2016. Core tenets of the theory of ecologically unequal exchange. Journal of Political Ecology 23(1): 446-466.

Palmer, M.A., E.S. Bernhardt, W.H. Schlesinger, K.N. Eshleman, E. Foufoula-Georgiou, M.S. Hendryx, A.D. Lemly, G.E. Likens, O.L. Loucks, M.E. Power, P.S. White and P.R. Wilcock. 2010. Mountaintop mining consequences. Science 327: 148-149.

Pomeranz, K. 2000. The great divergence China, Europe, and the making of the modern world economy. Princeton: Princeton University Press. 
Ramani, R.V. 2012. Surface mining technology: progress and prospects. Procedia Engineering 46: 9 - 21.

Sekyi, R. 2011. AKOBEN : Ghana's new initiative for environmental performance rating and disclosure in the mining sector. Proceedings Tailings and Mine Waste 2011 Vancouver, BC, November 6 to 9, 2011.

Sarfo-Mensah, P. and W. Oduro. 2007. Traditional natural resources management practices and biodiversity conservation in Ghana: a review of local concepts and issues on change and sustainability. The Fondazione Eni Enrico Mattei Note di Lavoro Series 90.

Safe Drinking Water Foundation [SWDF] n.d. Mining and water pollution fact sheet. Safe Drinking Water Foundation. https://www.safewater.org/fact-sheets-1/2017/1/23/miningandwaterpollution

Schueler, V., T. Kuemmerle and H. Schröder. 2011. Impacts of surface gold mining on land use systems in western Ghana. AMBIO: a Journal of the Human Environment 40: 528-539.

Tuokuu, F.X.D. 2019. Environmental policy assessment in the Ghanaian gold mining industry: insights from stakeholders. Unpublished PhD Dissertation, Antioch University New England.

UNDP. 2006. Human Development Report - beyond scarcity: power, poverty and the global water crisis. New York: UNDP.

UNDP. 2015. Final report: review of alignment between the Africa Mining Vision (AMV) and Ghana's policy/legal frameworks for solid minerals. Accra: UNDP.

Varris, P.A. and M.B. Thorpe. 2012. Community concerns and input for open pit closure in a West African urban setting. In Fourie, A.B. and M. Tibbett (eds.). Proceedings of the Seventh international conference on mine closure. Perth: Australian Centre for Geomechanics.

WACAM. 2018. The Wassa Association of Communities Affected by Mining website. WACAM, June 16. http://www.wacamghana.org/.

Wan, P.M.J. 2014. Environmental justices and injustices of large-scale gold mining in Ghana: A study of three communities near Obuasi. The Extractive Industries and Society 1: 38-47. 